\title{
ANALISIS KEMAMPUAN PEMECAHAN MASALAH MATEMATIKA SISWA PERBATASAN ENTIKONG (INDONESIA-MALAYSIA)
}

\author{
Puji Rahmawati ${ }^{1}$ dan Nurul Apsari ${ }^{2}$ \\ ${ }^{1}$ Dosen STKIP Melawi (Kampus Entikong) \\ ${ }^{2}$ Dosen STKIP Melawi
}

Jln. Kuari Yayasan Lintas Batas Kecamatan Entikong Kabupaten Sanggau

Jl. RSUD Melawi km. 04 Kec. Nanga Pinoh Kab. Melawi Kalimantan Barat puji_rahmawati89@yahoo.com, nurul.apsari89@gmail.com

\begin{abstract}
The changing process of currency between Rupiah and Ringgit based on observation is research is a serious problem that have to be noticed because it can incur losses in trade if the people do not understand about that. The lack of knowing in mathematics problem solving concept, especially in social aritmatic cause the loss happens easily. That is why, the researcher conducts this research in Suruh Tembawang village. It aims to know the competence of the third grade student's problem solving in Elementary School No.04 Punti Tapau and in Elementary School No.04 Punti Tapau. The Subjec of this research is all of the $3^{\text {th }}$ grade students in the public Elementary School No.04 Punti Tapau, and the object is mathematict problem solving competence. Whereas this research used quantitative analysis technique with percentage formula, and the instrument is test with some questions about mathematic problem solving competence. The method of this reasearch was a survey research the result of this research shows that the four steps of Problem Solving Competence based on Polya theory, there are two steps in Elementary School No.04 Punti Tapau. If it calculates in percentage, so that the step of mathematic problem solving competence Polya is $25 \%$.

Keywords: Problem Solving Competence, Elementary School, Entikong (A Border Area between Indonesia-Malaysia)
\end{abstract}

\begin{abstract}
Abstrak: Proses pertukaran mata uang antara rupiah dan ringgit menurut pengamatan peneliti adalah suatu masalah yang harus diperhatikan dan cukup serius, karna sering terjadinya kerugian masyarakat atas jual beli yang terjadi. Dikarenakan kurang mahirnya masyarakat di dalam penguasaan konsep pemecahan masalah matematika pada aritmatika sosial membuat kejadian ini sangat rentan akan terjadi. Terlebih anak-anak yang ikut serta melakukan perdagangan. Untuk itu peneliti melakukan penelitian di desa tersebut dengan tujuan untuk melihat kemampuan pemecahan masalah siswa kelas III di SDN No.04 Punti Tapau. Subjek penelitian ini adalah seluruh siswa kelas III di SDN No.04 Punti Tapau, dan objek penelitian ini adalah kemampuan pemecahan masalah matematika. Sedangkan tehnik analisis yang digunakan adalah analisis kuantitatif dengan rumus persentase, dan instrumen yang digunakan adalah soal tes kemampuan pemecahan masalah matematika. Adapun metode yang digunakan adalah penelitian survei dengan jenis penelitian survei catatan. Hasil dari penelitian menunjukkan bahwa dari keempat tahapan kemampuan pemecahan masalah menurut teori Polya, terdapat dua tahap yang muncul didalam pemecahan masalah yang dilakukannya. Tahapan tersebut adalah tahap memahami dan tahap melaksanakan rancangan solusi dari masalah yang disajikan. Jika
\end{abstract}


dipersentasekan maka langkah kemampuan pemecahan masalah matematika Polya yang dilaksanakan di SDN No.04Punti Tapau adalah sebanyak 25\%.

Kata kunci: Kemampuan Pemecahan Masalah, Sekolah Dasar, Entikong (Perbatasan Indonesia-Malaysia)

$\mathrm{P}_{\mathrm{p}}$ erdagangan di Entikong merupakan pemandangan yang biasa dilihat dan sudah menjadi budaya turun menurun, namun kenyataan yang terdapat di Entikong masih banyaknya terdapat keraguan di dalam penerapan ilmu matematika dalam bidang perdagangan. Padahal perdagangan dan matematika merupakan dua ilmu yang tidak dapat dibedakan. Perdagangan yang terjadi menggunakan mata uang rupiah (jika dijual ke Indonesia) dan mata uang ringgit (jika dijual ke Malaysia).

Nilai tukar rupiah dan ringgit selalu berubah, dan jarang sekali bertahan pada nilai tertentu. Hal ini membuat kebingungan dan kerap terjadi penipuan yang menimbulkan kerugian di masyarakat perbatasan Entikong. Kurang mahirnya masyarakat di dalam penguasaan konsep pemecahan masalah matematika pada aritmatika sosial menjadi salah satu penyebabnya.

Perdagangan yang berlangsung tidak hanya dilakukan oleh orang dewasa, tidak jarang ditemukan anak-anak pada usia sekolah yang turut serta berdagang. Dalam kondisi ini, peluang terjadinya penipuan semakin besar. Peluang itu semakin besar karena konsep aritmatika sosial yang diterima anak-anak tersebut masih di dalam tanda kutip sudah pernah didapatkah atau belum pernah sama sekali.

Aritmatika Sosial merupakan satu diantara cabang ilmu matematika yang sangat dekat dengan kehidupan masyarakat yang berprofesi sebagai tani dan pedagang. Kegiatan jual beli yang terjadi antar penduduk perbatasan haruslah dibarengi dengan kecakapan aritmatika sosial yang dimilikinya. Kegiatan jual beli yang melibatkan semua usia tersebut sangatlah rentan dengan penipuan dan kerugian jika tidak dibarengi dengan pengetahuan dan penguasaan konsep aritmatika sosial. Dengan alasan inilah peneliti berniat ingin melahirkan sebuah model pembelajaran yang dapat membantu dalam pemahaman konsep kemampuan pemecahan masalah yang disesuaikan dengan keadaan masyarakat perbatasan. Sebelum lahirnya model pembelajaran tersebut, peneliti akan melakukan penelitian dengan menganalisis kemampuan pemecahan masalah aritmatika sosial siswa kelas III dari SD yang memiliki akreditasi C dari satu sekolah di perbatasan Entikong (SDN No.04Punti Tapau).

Pembelajaran yang umumnya dilakukan untuk mengatasi hal ini adalah 
dengan pembelajaran berbasis masalah. Pembelajaran berbasis masalah biasanya dikenal juga dengan PBL (Problem Based Learning). PBL merupakan pembelajaran yang memfokuskan kepada pemecahan dan atau penyelesaian masalah, di dalam PBL pemecahan masalah merupakan trik menyelesaikan masalah. Hal ini sesuai dengan pendapat Wena (2014: 52) bahwa pemecahan masalah dipandang sebagai suatu proses untuk menemukan kombinasi dari sejumlah aturan yang dapat diterapkan dalam upaya mengatasi situasi yang baru.

Menurut Fatimah (2012: 251) PBLadalah salah satu model pembelajaran memiliki ciri khas yaitu selalu dimulai dan berpusat pada masalah. Di dalam PBL siswa dapat bekerja di dalam kelompokkelompok kecil dan harus mengidentifikasi apa yang mereka ketahui serta apa yang mereka tidak ketahui dan harus belajar untuk memecahkan suatu masalah. Peran utama dari pengajar adalah untuk memudahkan proses kelompok dan belajar, bukan untuk menyediakan jawaban secara langsung.

Kemampuan matematika dapat didefinisikan oleh NCTM (Solaikah dkk, 2013) sebagai, "Mathematical power includes the ability to explore, conjecture, and reason logically; to solve non-routine problems; to communicate about and through mathematics; and to connect ideas within mathematics and between mathematics and other intellectual activity.". Lebih lanjut selain kemampuan untuk menggali, menyusun konjektur, dan membuat alasan-alasan secara logis, untuk memecahkan masalah nonrutin, untuk berkomunikasi mengenai dan melalui matematika, dan untuk menghubungkan berbagai ide-ide dalam matematika dan diantara matematika dan aktivitas intelektual lainnya.

$$
\text { Selain itu, Anderson }
$$
memaparkan bahwa, "Problem solving is recognised as an important life skill involving a range of processes including analysing, interpreting, reasoning, predicting, evaluating and reflecting.", yang artinya bahwa "Pemecahan masalah diakui sebagai keterampilan hidup yang penting yang melibatkan berbagai proses termasuk menganalisis, menafsirkan, menalar, memperkirakan, mengevaluasi, dan merefleksikan.”. Dengan demikian, pemecahan masalah merupakan hal penting yang tidak dapat dipisahkan dari kehidupan kita, yang secara tidak langsung sering kita gunakan dalam kehidupan sehari-hari kita.

Dalam pembelajaran, peserta didik memperoleh pengalaman dengan menggunakan pengetahuan serta keterampilan yang telah dimiliki untuk diterapkan dalam memecahkan masalah yang bersifat tidak rutin. Dengan demikian, setiap guru dan yang terkait dengan 
masalah pengembangan pendidikan seharusnya berusaha dan mampu melakukan perbaikan dan pengembangan pembelajaran matematika dalam upaya meningkatkan kemampuan peserta didik, yakni kemampuan pemecahan masalah matematis. (Syaharuddin, 2016).

Dikarenakan kemampuan pemecahan masalah matematika bagi anak dusun Suruh Tembawang sangat penting, untuk menyelesaikan permasalahan ini langkah awal yang akan dilakukan adalah menganalisis tingkat kemampuan pemecahan masalah siswa saat ini. Menurut Roebyanto dan Harmini (2017: 34-35) analisis kemampuan pemecahan masalah siswa dapat dilakukan dengan mengacu pada teoriPolya, yaitu sebagai berikut.

1. Pemahaman masalah (understanding the problem), misalnya meliputi:

a. Apakah yang tidak diketahui? Data apakah yang diberikan? Bagaimana kondisi soal?

b. Mungkinkah kondisi dinyatakan dalam bentuk persamaan atau hubungan lainnya?

c. Apakah kondisi yang diberikan cukup untuk mencari apa yang ditanyakan?

d. Apakah kondisi tersebut tidak cukup? Apakah kondisi itu berlebihan atau itu saling bertentangan. e. Buatlah gambar atau tuliskan notasi yang sesuai.

2. Perencanaan penyelelesaian (devising a plan), misalnya meliputi:

a. Pernahkah Anda menemukan soal seperti ini sebelumnya? Pernahkah ada soal yang serupa dalam bentuk lain?

b. Teori mana yang dapat digunakan dalam masalah ini?

c. Perhatikan apa yang dinyatakan atau coba pikirkan soal yang pernah diketahui dengan pertanyaan yang sama atau yang serupa. Andaikan ada soal yang mirip dengan soal yang pernah diselesaikan, dapatkah pengalaman itu digunakan dalam masalah yang sekarang?

d. Dapatkah hasil dan metode yang lalu digunakan di sini?

e. Apakah harus dicari unsur lain agar dapat memanfaatkan soal semula, mengulang soal tadi atau menyatakan dalam bentuk lain? Kembalilah pada definisi.

f. Andaikan soal baru belum dapat diselesaikan, coba pikirkan soal serupa dan diselesaikan. Bagaimana bentuk soal tersebut?

g. Bagaimana bentuk soal yang lebih khusus?

h. Misalkan sebagian kondisi dibuang, sejauh mana yang ditanyakan dalam soal dapat dicari? Manfaat apa yang 
dapat diperoleh dengan kondisi sekarang?

i. Dapatkah apa yang ditanyakan, data atau keduanya diubah sehingga menjadi saling berkaitan satu dengan yang lainnya?

j. Apakah semua data dan kondisi sudah digunakan? Sudahkah diperhitungkan ide-ide penting yang ada dalam soal tersebut?

3. Melaksanakan perencanaan (carrying out the plan), misalnya meliputi:

a. Memeriksa setiap langkah apakah sudah benar atau belum?

b. Bagaimana membuktikan bahwa langkah yang dipilih sudah benar?

4. Pemeriksaan kembali proses dan hasil (looking back), hal ini meliputi:

a. Dapatkah diperiksa sanggahannya?

b. Dapatkah jawaban tersebut dicari dengan cara lain?

c. Dapatkah anda melihatnya secara sekilas?

d. Dapatkah cara atau jawaban tersebut digunakan untuk soal-soal lain?

Artikel ini bertujuan untuk memaparkan peta kemampuan pemecahan masalah matematika siswa perbatasan, khususnya siswa di SDN No.04Punti Tapau. Peta kemampuan pemecahan masalah matematika siswa ini diamati sesuai dengan teori kemampuan pemecahan masalah Polya.

\section{METODE}

Metode penelitian yang digunakan di dalam penelitan ini adalah penelitian survei dengan jenis penelitian survei catatan. Jenis penelitian survei catatan sering disebut juga dengan penelitian survey of records, karena dalam kegiatan penelitian ini banyak menggunakan sumber-sumber yang berupa catatan atau informasi nonreaksi. Menurut Darmadi (2014: 274) penelitian survei catatan mempunyai keuntungan dibanding dengan model lainnya, yaitu bahwa objektivitas informasi yang diperoleh lebih objektif dan bisa dipertanggungjawabkan. Tahapan penelitian yang dilakukan pada penelitian ini adalah sebagai berikut.

1. Menentukan tujuan dan skope survei,

2. Mendesain angket atau petunjuk wawancara,

3. Mendesain soal pemecahan masalah matematika materi aritmatika sosial,

4. Menyebarkan surat izin ujicoba instrumen dan surat izin penelitian ke SDN No.12 Entikong, serta meminta surat balasan terkait hal tersebut,

5. Mengetes instrumen untuk mengidentifikasi dan memperbaiki item yang kurang relevan, dan mencapai format yang baik, mudah ditabulasi dan dianalisis,

6. Melakukan penyebaran instrumen ke sekolah terkait untuk diteskan kepada 
siswa kelas III SDN No.04Punti

Tapau.

Melakukan analisis hasil tes tersebut untuk melihat sejauhmana tingkat kemampuan pemecahan masalah matematika materi aritmatika sosial, dan angket atau wawancara untuk melihat bentuk pembelajaran yang terjadi selama ini. Prosedur penelitian ini dapat dilihat pada bagan di bawah ini.

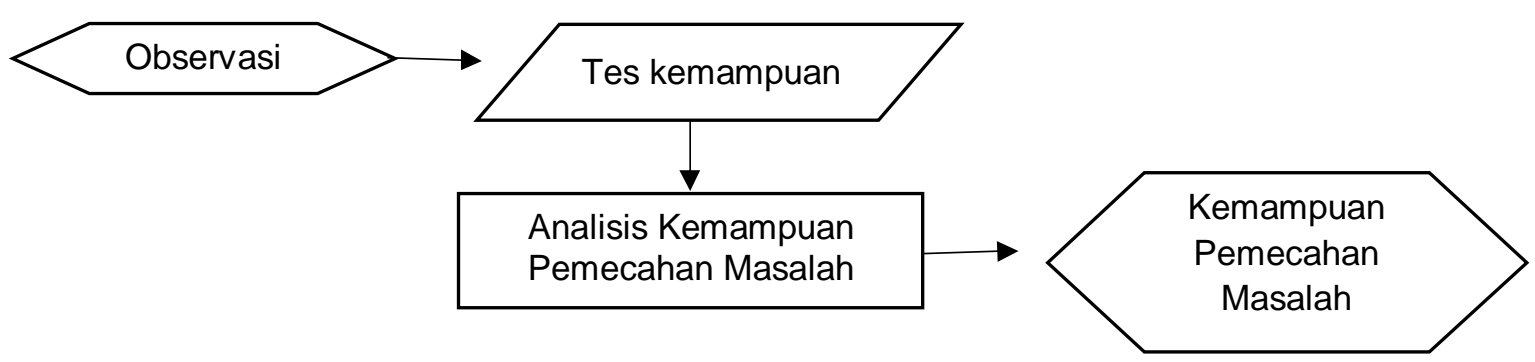

Gambar 1. Prosedur Penelitian

Teknik analisis data untuk data hasil penelitian ini adalah analisis kuantitatif. Analisis kuantitatif yang digunakan pada penelitian ini adalah dengan menggunakan rumus persentase, persantase berguna untuk melihat kemampuan pemecahan masalah siswa di SDN No.04 Punti Tapau. Selain itu data tersebut didukung dengan hasil wawancara dengan guru setempat untuk memperkuat pendeskripsian data hasil penelitian.

\section{HASIL PENELITIAN DAN PEMBAHASAN}

1. Uji validitas Instrumen Tes

Kemampuan Pemecahan Masalah Instrumen tes kemampuan pemecahan masalah berupa soal essay sebanyak 25 soal. Validitas yang digunakan oleh peneliti adalah validitas isi (dilakukan oleh para ahli) dan validitas empiris (diujicobakan di SDN No.12 Entikong). Peneliti melakukan validasi isi instrumen ke dua orang ahli, yaitu seorang ahli matematika (Vera Riyanti, M.Pd, magister pendidikan matematika) dan seorang ahli bahasa (Agustina Fini Widya, M.Pd, magister bahasa indonesia). Validasi ini berlangsung selama dua kali hingga tes kemampuan pemecahan masalah dikatakan valid dan layak untuk digunakan didalam penelitian ini.

Sedangkan validitas empiris dilakukan di kelas III SDN No.12 Entikong, validitas ini dilakukan dengan tujuan memperoleh soal pemecahan masalah yang layak digunakan sebagai alat pengumpul data di SDN No.04Punti Tapau. Hasil validitas ini selanjutnya dihitung tingkat kesulitan butir soal, daya beda, dan reliabilitasnya.

Indeks kesukaran butir tes diklasifikasikan sebagai : sangat mudah, mudah, sedang, sukar, atau sangat sukar sesuai dengan kriteria berikut ini. 
Tabel 1. Kriteria Indeks Kesukaran Butir Tes

\begin{tabular}{cc}
\hline IK & Interprestasi Indeks Kesukaran \\
\hline $0,00 \leq \mathrm{IK}<0,20$ & Butir tes sangat sukar \\
$0,20 \leq \mathrm{IK}<0,40$ & Butir tes sukar \\
$0,40 \leq \mathrm{IK}<0,60$ & Butir tes sedang \\
$0,60 \leq \mathrm{IK}<0,90$ & Butir tes mudah \\
$0,90 \leq \mathrm{IK}<1,00$ & Butir tes sangat mudah \\
\hline
\end{tabular}

Rumus indeks kesukaran (IK) untuk tes uraian yaitu:

$$
I K=\frac{n_{A}+n_{B}}{N_{A}+N_{B}}
$$

Keterangan:

IK = Indeks kesukaran $n_{A}=$ banyaknya siswa kelompok atas yang menjawab soal benar $n_{B}=$ banyaknya siswa kelompok bawah yang menjawab soal benar $N_{A}=$ banyaknya siswa kelompok atas $N_{B}=$ banyak siswa kelompok bawah

Menurut Lestari dan Yudhanegara (2017:224), suatu butir soal dikatakan memiliki indeks kesukaran yang baik jika soal tersebut tidak terlalu mudah dan tidak terlalu sukar. Dengan demikian, kriteria indeks kesukaran yang digunakan di dalam penelitian ini adalah pada rentang $0,40 \leq$ IK $<0,60$ dengan kriteria interpretasi indeks kesukaran pada kriteria "butir tes sedang".

Instrumen tes ini diujicobakan ke siswa kelas III SDN No.12 Entikong. Hasil tes ujicoba tersebut membuahkan hasil bahwa semua soal harus dirubah, karena berada pada tingkat kesukaran kategori sulit. Oleh karena itu instrumen diperbaiki dengan mengganti atau merubah ke-25 soal tersebut dengan soal yang baru.

Soal tes yang telah diperbaiki selanjutnya dilakukan ujicoba kembali. Ujicoba kedua ini telah berada pada kriteria "butir tes sedang". Selanjutnya perhitungan daya beda butir tes. Perhitungan daya beda butir tes uraian menggunakan rumus sebagai berikut.

$$
D P=\frac{n_{A}-n_{B}}{N_{A}} \text { atau } D P=\frac{n_{A}-n_{B}}{N_{B}}
$$

Keterangan:

$\mathrm{DP}=$ indeks daya pembeda butir soal $n_{A}=$ banyaknya siswa kelompok atas yang menjawab soal benar $n_{B}=$ banyaknya siswa kelompok bawah yang menjawab soal benar $N_{A}$ = banyaknya siswa kelompok atas $N_{B}=$ banyak siswa kelompok bawah

Tinggi atau rendahnya tingkat daya pembeda suatu butir soal dinyatakan dengan indeks daya pembeda (DP). Kriteria yang digunakan untuk menginterprestasikan indeks daya pembeda disajikan (Lestari dan Yudhanegara, 2017 : pada tabel berikut: 
Tabel 2. Kriteria Indeks Daya Pembeda Butir Tes

\begin{tabular}{cc}
\hline Nilai & Interprestasi Daya Pembeda \\
\hline $0,70<\mathrm{DP} \leq 1,00$ & Sangat baik \\
$0,40<\mathrm{DP} \leq 0,70$ & Baik \\
$0,20<\mathrm{DP} \leq 0,40$ & Cukup \\
$0,00<\mathrm{DP} \leq 0,20$ & Buruk \\
$\mathrm{DP} \leq 0,00$ & Sangat buruk \\
\hline
\end{tabular}

Berdasarkan tabel tersebut di atas, rentang yang digunakan di dalam penelitian ini adalah pada $0,40<\mathrm{DP} \leq 0,70$ atau dengan interpretasi daya pembeda "baik". Berdasarkan hasil tes uji coba, ke25 tes tersebut telah memenuhi interpretasi "baik".

Selanjutnya perhitungan reliabilitas instrumen tes. Untuk menentukan reliabilitas instrumen tes tipe subjektif yang digunakan peneliti pada penelitian ini adalah rumus Kuder dan Richardson ke-20. Rumus ini digunakan untuk jenis data yang dihasilkan adalah dikotomi kontinu, di mana penskoran dilakukan berdasarkan dua kriteria $(1=$ benar dan $0=$ salah $)$. Menurut Lestari dan Yudhanegara
(2017:206), rumus Alpha Cronbach sebagai berikut:

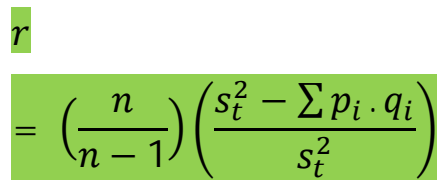

Keterangan:

$r=$ koefisien reliabilitas instrumen

$n$ = banyaknya butir soal

$p_{i}=$ proporsi banyaknya subjek yang menjawab benar pada butir soal ke-i

$q_{i}=$ proporsi banyaknya subjek yang menjawab salah pada butir soal ke-i

$s_{t}^{2}=$ varians skor total

Lestari dan Yudhanegara (2017: 206) menuliskan tolak ukur untuk menginterprestasikan derajat reliabilitas instrumenditentukan berdasarkan kriteria Guilford pada tabel berikut:

Tabel 3. Kriteria Koefisien Korelasi Reliabilitas Instrumen

\begin{tabular}{ccl}
\hline Koefisien Korelasi & Korelasi & \multicolumn{1}{c}{ Interpretasi Reliabilitas } \\
\hline $0,90 \leq \mathrm{r} \leq 1,00$ & Sangat tinggi & Sangat tetap/sangat baik \\
$0,70 \leq \mathrm{r}<0,90$ & Tinggi & Tetap / baik \\
$0,40 \leq \mathrm{r}<0,70$ & Sedang & Cukup tetap/ cukup baik \\
$0,20 \leq \mathrm{r}<0,40$ & Rendah & Tidak tetap/ buruk \\
$\mathrm{r}<0,20$ & Sangat rendah & Sangat tidak tetap/ sangat buruk \\
\hline
\end{tabular}

Setelah melakukan perhitungan diperoleh nilai reliabilitas berada minimal pada rentang koefesien korelasi $0,40 \leq \mathrm{r}<$ 0,70, sehingga korelasi pada kategori sedang dan interpretasi reliabilitasnya adalah cukup tetap/cukup baik.

2. Hasil Penelitian

Penelitian ini dilakukan di SDN No.04Punti Tapau. Penelitian yang telah 
dilakukan peneliti selama kurang lebih dua bulan ini memberikan informasi yang menggambarkan kemampuan pemecahan masalah siswa kelas III di sekolah tersebut.
Adapun keadaan kemampuan pemecahan masalah siswa dapat tergambar di dalam tabel di bawah ini.

Tabel 4. Peta Kemampuan Pemecahan Masalah Siswa

\begin{tabular}{|c|c|c|c|c|c|}
\hline \multirow{2}{*}{ Sekolah } & \multirow{2}{*}{ Siswa } & \multicolumn{4}{|c|}{ Kemampuan Pemecahan Masalah Polya } \\
\hline & & Memahami & Merencanakan & Melaksanakan & Memeriksa Kembali \\
\hline & Lusiana & & & & $\sqrt{ }$ \\
\hline & Epriliana & & & & $\sqrt{ }$ \\
\hline & Evi & & & & \\
\hline SDN & Zil Panus & & & & $\sqrt{ }$ \\
\hline No.04Pu & Darwin & & & & \\
\hline nti Tapau & Nesi & & & & $\sqrt{ }$ \\
\hline & Kristian & & & & $\sqrt{ }$ \\
\hline & Revi & & & & $\sqrt{ }$ \\
\hline & Madu & & & & $\sqrt{ }$ \\
\hline
\end{tabular}

Berdasarkan tabel di atas, dapat dilihat dengan jelas bahwa kemampuan pemecahan masalah siswa di SDN No.04Punti Tapau masih rendah. Selanjutnya, jika dilihat berdasarkan teori Polya maka dapat ditarik kesimpulan bahwa kemampuan pemecahan masalah matematika siswa kelas III SDN No.04Punti Tapau yang muncul hanyalah tahap keempat (memeriksa kembali). Dari keempat tahap pemecahan masalah matematika siswa tersebut hanya mampu berada pada tahap memeriksa kembali, sedangkan langkah lainnya belum termasuk ke dalam tahapan penyelesaian masalah yang dilakukan siswa kelas III di SDN tersebut. Jadi $25 \%$ tahap pemecahan masalah (sesuai teori Polya) yang dilakukan siswa. Jika dibuat sebuah diagram, maka dapat dilihat sebagai berikut.

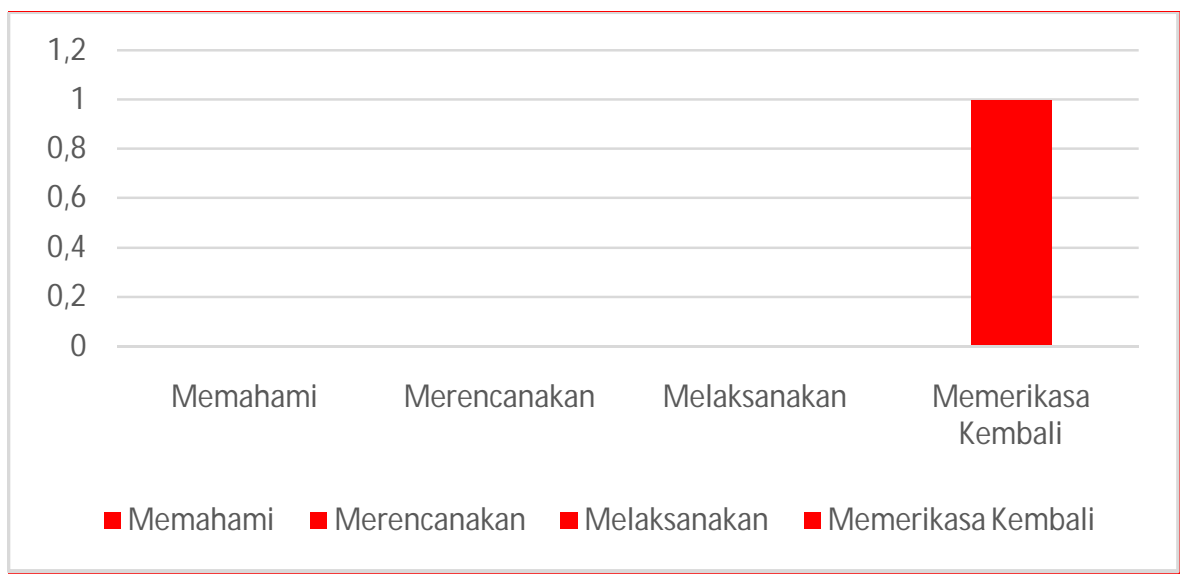

Gambar 2. Banyaknya Siswa yang Melaksankan Tahap Pemecahan Masalah Polya 
Subjek yang memiliki kemampuan pemecahan masalah yang rendah cenderung mengalami masalah dalam mengakses informasi dan menuliskannya dalam bentuk simbol atau notasi matematika (Maftuh, 2018). Pendapat tersebut sesuai dengan hasil penelitian ini. Siswa masih kesulitan didalam memahami masalah dan menuliskannya dalam bentuk simbol atau notasi matematika. Hal ini didorong karena pembelajaran dengan pemecahan masalah belum pernah diterapkan di sekolah tersebut. Karena menurut Zahriah, Hasan dan Jalil (2016) pembelajaran dengan pemecahan masalah model Polya siswa dibimbing untuk berpikir lebih dalam ketika menyelesaikan masalah, memahami masalah dengan merepresentasikan dalam bentuk gambar dan diagram, sehingga hasil yang didapatkan dari proses pemecahan masalah menjadi lebih bermakna dan bukan hanya berbentuk angka.

Pada penyelesaian pemecahan masalah, siswa cenderung sulit dalam mengkomunikasikan pernyataan yang diketahui kedalam bentuk matematis. Ketidakmampuan mereka dapat terlihat saat harus menjelaskan dan menyelesaikan permasalahan matematika terhadap teman sejawat di depan kelas. (Mahanani dan Murtiyasa, 2016). Menurut Yarmayani (2016) ketidaktepatan indikator tersebut (pemecahan masalah) karena kebanyakan subjek tidak sistematis dalam penulisan penyelesaian soal. Indikator yang dimaksud adalah indikator kemampuan pemecahan masalah teori Polya. Siswa yang tidak dapat menyelesaikan masalah sesuai dengan tahapan kemampuan pemecahan masalah Polya menurut Yarmani mereka cenderung tidak runtut dalam menuliskan penyelesaian dari masalah yang disajikan.

Pemilihan model pembelajaran yang tepat penting dilakukan oleh guru guna mengoptimalkan kemampuan pemecahan masalah siswa. Kemampuan pemecahan masalah merupakan salah satu keterampilan yang penting untuk menghadapi era informasi seperti saat ini untuk berkompetisi dalam masyarakat global dengan segala kemajuan. (Kurniawati, 2017).

Ditinjau dari kemampuan dalam menyelesaikan soal pemecahan masalah yang sering disajikan dalam bentuk soal cerita, Wahyuddin (2016) dalam penelitiannya mengatakan bahwa “....semakin baik atau semakin tinggi kemampuan verbal yang dimiliki oleh siswa maka kemampuan menyelesaikan soal cerita siswa tersebut akan semakin baik atau semakin tinggi.". Siswa SDN No.04Punti Tapau cenderung mengalami kesusahan di dalam menyelesaikan masalah matematika di dalam bentuk soal cerita. Hal ini membuat siswa merasa sulit dalam 
memahami dan menuliskannya dalam bentuk simbol atau notasi matematika.

Hasil penelitian sejenis dengan penelitian ini adalah penelitian yang dilakukan oleh Netriwati pada tahun 2016. Hasil penelitiannya menunjukkan bahwa mahasiswa dengan tingkat pengetahuan awal tinggi berpikir secara algoritmik dalam menyelesaikan soal pemecahan masalah matematis yaitu mampu memahami masalah dengan benar dan lancar. Untuk mahasiswa dengan tingkat pengetahuan awal sedang mereka berpikir secara algoritmik dan belum sempurna dalam menyelesaikan soal pemecahan masalah. Kemudian mahasiswa dengan tingkat pengetahuan awal rendah berpikir secara heuristik dalam menyelesaikan soal pemecahan masalah matematis. Hasil penelitian Netriwati membagi objek penelitiannya menjadi tiga bagian, jika disamakan dengan penelitian ini maka subjek penelitian ini berada pada kondisi siswa yang memiliki pengetahuan awal rendah sehingga pola berpikirnya untuk menyelesaikan masalah adalah dengan berpikir secara heuristik.

Selain itu penelitian serupa juga dilakukan oleh Mahardhikawati, Mardiyana, dan Setiawan, pada tahun 2013/2014 yang dipublikasikan pada tahun 2017. Hasil penelitian ini dapat dipaparkan sebagai berikut. (1) Kemampuan pemecahan masalah siswa dengan kecerdasan logis-matematis tinggi adalah: siswa mampu menentukan apa yang diketahui dan ditanyakan dengan tepat; siswa mampu membuat rencana pemecahan masalah dengan tepat; siswa mampu melakukan langkah-langkah rencana pemecahan masalah dengan tepat; siswa mampu menentukan solusi alternatif untuk memecahkan masalah; tidak semua siswa memeriksa jawabannya kembali. Kemampuan pemecahan masalah siswa dengan kecerdasan logis-matematis sedang adalah: siswa mampu menentukan apa yang diketahui dan ditanyakan dengan tepat; siswa mampu membuat rencana pemecahan masalah namun tidak terlalu tepat; siswa mampu melakukan langkah-langkah rencana pemecahan masalah; tidak semua siswa mampu menentukan solusi alternatif untuk memecahkan masalah dan memeriksa jawabannya kembali. (3) Kemampuan pemecahan masalah siswa dengan kecerdasan logis-matematis rendah adalah: siswa mampu menentukan apa yang diketahui dan ditanyakan dengan tepat; siswa tidak mampu membuat rencana pemecahan masalah yang tepat; siswa mampu melakukan langkah-langkah rencana pemecahan masalah; siswa tidak mampu menentukan solusi alternatif untuk memecahkan masalah dan tidak memeriksa jawabannya kembali. Jika dilihat dari hasil 
penelitian ini dan jika dibandingkan dengan hasil penelitian yang dilakukan oleh peneliti, maka dapat disimpulkan bahwa kemampuan pemecahan masalah siswa perbatasan berada pada tinggat kemampuan logis-matematis rendah.

Berdasarkan hasil penelitian yang dilakukan oleh Netriwati dan Mahardhikawati, Mardiyana, dan Setiawan; serta hasil penelitian yang dilakukan oleh peneliti, maka siswa perbatasan memiliki kemampuan awal rendah dan tingkat kemampuan logis-matematisnya rendah. Hal ini berakibat kepada rendahnya kemampuan pemecahan masalah siswa perbatasan.

\section{SIMPULAN}

Berdarkan hasil pemetaan kemampuan pemecahan masalah matematika yang terdapat pada tabel 4 diperoleh hasil bahwa kemampuan pemecahan masalah matematika siswa di SDN No.04Punti Tapau masih rendah. Berdasarkan teori Polya, tahap-tahap pemecahan masalah ada empat tahapan, yaitu kemampuan memahami permasalahan, kemampuan merencanakan penyelesaian, kemampuan menjalankan rencana penyelesaian, dan kemampuan melihat kembali. Siswa di SDN tersebut hanya menggunakan satu tahap penyelesaian pemecahan masalah, yiatu tahap memeriksa kembali. Karena tahapan yang dilakukan oleh siswa ada satu tahap dari empat tahap, maka dapat disimpulkan bahwa kemampuan pemecahan masalah siswa SDN No.04Punti Tapau adalah sebanyak $25 \%$.

\section{DAFTAR PUSTAKA}

Anderson, J. 2009. Mathematics Curiculum Development and the Role of Problem Solving. Associate Professor in Mathematics Education Conference. ACSA (Autralian Curriculum Studies Association inc) at Australia.

Darmadi, H. 2014. Metode Penelitian Pendidikan dan Sosial Teori Konsep Dasar dan Implementasi. Bandung: Alfa Beta.

Fatimah, F. 2012. "Kemampuan Komunikasi Matematis Dan Pemecahan Masalah Melalui Problem Based-Learning”. Jurnal Penelitian dan Evaluasi Pendidikan, 16(1), 249259.

Kurniawati, W. 2017. Analisis Kemampuan Pemecahan Masalah Menurut Polya dalam Pembelajaran Problem Based Learning Berdasarkan Gaya Berpikir Gregorc Siswa Kelas VII SMP Negeri 1 Gondang Tahun Ajaran 2016/2017. Skripsi pada Universitas Muhammadiyah Surakarta. 
Lestari, K. E., \& Yudhanegara, M.R. 2017. Penelitian Pendidikan Matematika. Bandung: PT. Refika Aditama.

Maftuh, M. S. 2018. "Profil Siswa SMA dalam Memecahkan Maslah Statistika Berdasarkan Tingkat Kemampuan Matematika". Fibonacci: Jurnal Pendidikan Matematika dan Matematika, 4 (1), 71-86.

Mahanani, Linggar, G., dan Murtiyasa, Budi. 2016. Kemampuan Pemecahan Masalah Matematika Aljabar Berbasis Timss pada Siswa SMP Kelas VIII. Prosiding SEMPOA (Seminar Nasional, Pemeran Alat Peraga, dan Olimpiade Matematika). Universitas Muhammadiyah Surakarta.

Mahardhikawati, Ema., Mardiyana, dan Setiawan. $2017 . \quad$ "Analisis Kemampuan Pemecahan Masalah Berdasarkan Langkah-langkah Polya pada Materi Turunan Fungsi Ditinjau dari Kecerdasan Logis-Matematis Siswa Kelas XI IPA SMA Negeri 7 Surakarta Tahun Ajaran 2013/2014". Jurnal Pendidikan Matematika dan Matematika (JPMM), 1(4),119-128.

Netriwati. 2016. “Analisis Kemampuan Pemecahan Masalah Matematis Berdasarkan Teori Polya ditinjau dari Pengetahuan Awal Mahasiswa IAIN Raden Intan Lampung". Al-Jabar:
Jurnal Pendidikan Matematika. 7 (2), 181-190.

Roebyanto, G., dan Harmini, S. 2017. Pemecahan Masalah Matematika untuk PGSD. Bandung: Remaja Rosdakarya.

Solaikah. 2013. "Identifikasi Kemampuan Siswa dalam Menyelesaikan Soal Aritmatika Sosial Ditinjau dari Perbedaan Kemampuan Matematika". Jurnal Pendidikan Matematika STKIP PGRI Sidoarjo. 01(01), 97106.

Syaharuddin. 2016. Deskripsi Kemampuan Pemecahan Masalah Matematika dalam Hubungannya dengan Pemahaman Konsep Ditinjau dari Gaya Belajar Siswa Kelas VIII SMPN

4 Binamu Kabupaten Jeneponto. Tesis di Universitas Negeri Makasar. Wahyuddin. 2016. “Analisis Kemampuan Menyelesaikan Soal Cerita Matematika Ditinjau dari Kemampuan Verbal". Jurnal Beta. 9(2), 148-160.

Wena, M. 2014. Strategi Pembelajaran Inovatif Kontemporer Suatu Tinjauan Konseptual Operasional. Jakarta: Bumi Aksara.

Yarmayani, A. 2016. "Analisis Kemampuan Pemecahan Masalah Matematis Siswa Kelas XI Mipa 
SMA Negeri 1 Kota Jambi”. Jurnal Ilmiah Dikdaya. 06(2), 12-19.

Zahrian., Hasan, M., dan Jalil, Zulkarnain. 2016. "Penerapan Pemecahan Masalah Model Polya untuk Meningkatkan Kemampuan Analisis dan Hasil Belajar pada Materi Vektor di SMAN 1 Darul Iman”. Jurnal Pensisikan Sains Indonesia Universitas Syiah Kuala Banda Aceh. 04 (02), 151-161. 